\title{
The Use of the Communicative Language Teaching Approach to Improve Students' Oral Skills
}

\author{
Vanessa Toro ${ }^{1}$, Gina Camacho-Minuche ${ }^{1}$, Eliana Pinza-Tapia ${ }^{1} \&$ Fabian Paredes ${ }^{1}$ \\ ${ }^{1}$ Universidad Técnica Particular de Loja, Ecuador \\ Correspondence: Vanessa Toro, Universidad Técnica Particular de Loja, Ecuador.
}

Received: October 28, 2018 Accepted: December 11, 2018 Online Published: December 14, 2018

doi: 10.5539/elt.v12n1p110 URL: https://doi.org/10.5539/elt.v12n1p110

\begin{abstract}
The purpose of this study is to determine the use of the Communicative Language Teaching approach in the English classroom and the strategies and resources used by the teachers to improve students' oral skills. The participants were 6 English teachers and 105 students enrolled in the 2nd, 3rd, and 4th grades at a public elementary school in the city of Loja, located at the southern part of Ecuador. A mixed method approach was applied in this study. In order to collect the data, a questionnaire was given to the English teachers and class observations were carried out. The results obtained throughout this study reveal that modeling, repetition, pair and group work are the main strategies used by teachers to help students develop communicative competences. These strategies were frequently used but still not enough to promote active participation during classes. It is important to highlight that there is a variety of strategies besides the ones previously mentioned that can be incorporated to offer students more opportunities to orally produce the language. Additionally, teachers provide different kinds of feedback such as metalinguistic feedback and elicitation as a way to help students improve their oral skills.
\end{abstract}

Keywords: communicative language teaching, EFL teaching, feedback, strategies, oral skills

\section{Introduction}

There are different methods that are being used to teach English as a foreign language but not all of them help us to reach the desired communicative goals; therefore, the selection and application of the most effective ones is required. In Ecuador, the lack of appropriate methods, techniques, and strategies for teaching English is providing poor results in the oral production of the language. The study conducted by Calle, Calle, Argudo, Moscoso, Smith, and Cabrera (2012) indicates that the strategies teachers use in the English classroom are based on traditional methods that do not focus on the Communicative Language Teaching approach as it is established by the Ministry of Education and Culture of Ecuador. They also highlight that English classes are teacher-centered rather than student-centered and most of them are conducted in Spanish which limit the acquisition of the target language. It is also necessary to mention that the English curriculum in Ecuador has established that for the "subnivel de básica elemental" $\left(2^{\text {nd }}, 3^{\text {rd }}\right.$, and $4^{\text {th }}$ grades $)$ and for the "subnivel de básica media" $\left(5^{\text {th }}, 6^{\text {th }}\right.$, and $7^{\text {th }}$ grades), students receive 3 hours of English classes during the week; for the subnivel de básica superior $\left(8^{\text {th }}, 9^{\text {th }}\right.$, and $10^{\text {th }}$ grades), students receive 5 hours of English classes per week. With respect to "Bachillerato General Unificado", students from $1^{\text {st }}$ and $2^{\text {nd }}$ grades receive 5 hours of English per week while the students from $3^{\text {rd }}$ grade receive 3 hours per week; consequently, the time assigned for English classes in Ecuador are not sufficient for students to develop their communicative competence.

Additionally, according to the results obtained by the British Council (2015), English learners in Ecuador show more confidence at the time of reading and writing but they do not have much confidence in speaking. English learners consider speaking harder than writing and reading and the only contact they have with the language is in classes, besides that, they do not count on teachers who use appropriate strategies to encourage them to produce the language. As a solution to this problem, the English curriculum of Ecuador 2016 was improved considering the Communicative Language Teaching Approach as one of the core principles. This approach involves learning a language through interaction and communication, rather than learning it through memorization of different aspects of the language system. For this reason, the purpose of this study is to determine if the Communicative Language Teaching approach is being used in the English classroom to improve students' oral skills and which strategies and resources are mainly used by teachers regarding this approach. Finally, English teachers and education authorities will benefit from these results because of the valuable information about the implementation of the 
Communicative Language Teaching Approach in the English classroom they will provide.

These results will represent a great source of information about the community involved in the educational field which will contribute to the improvement of the teaching and learning language process in the use of appropriate methods.

\section{Literature Review}

\subsection{Communicative Language Teaching Approach}

All human beings need to communicate in order to express their ideas, feelings and thoughts, this is the main reason why communicative activities should be integrated into the lesson. Students spoken language is more productive when they are engaged in a dynamic learning environment that encourages them to do their tasks.

It is well-known that all people need to understand spoken language in different situations, such as daily life, work, school, community, among others. According to Moss and Ross-Feldman (2003), any activity which requires the learner to speak and listen to others includes the use of communication. Activities with communicative purposes are helpful for breaking down barriers, finding information, expressing ideas about oneself and learning about culture.

Jeyasala (2014) asserts that teachers should encourage students' communicative competence all the time, and besides their limitations to use language fluently and accurately, they should provide them with spaces to interact with others or to immerse them in speaking activities that enhance their ability to use the target language.

Providing students with real communicative contexts is the best option teachers can make, because students can exchange real information, so language and phrases will emerge according to the situation. It is also necessary that students have a lot of exposure to the language, the linguistic input they receive should provide them with opportunities to produce and use the language at any situation, motivation then plays a very important role in encouraging students to verbally communicate.

According to Richards (2006), learning the language does not always guarantee the learner will be able to use the language fluently. Consequently, the lack of fluency can be the result of rigid formal training in language learning; another reason can be the lack of strategies to involve students in communicative activities. Learners should be encouraged to take the initiative to participate and dare to express their ideas, it does not matter whether they use the language properly, but at least, they need to try and improve it through constant practice.

The author also asserts that communicative competence involves the following aspects of language knowledge: knowing how to use the language in different situations, knowing how to vary the use of the language according to settings and participants (formal and informal speech), being able to understand different types of texts, and knowing how to maintain communication despite any limitation the speaker might have.

When using communicative activities in the classroom, a distinction between fluency and accuracy should be done, understanding fluency as the natural language use that takes place when the speakers participate in a conversation despite the limitation of their communicative competence. Accuracy, on the other hand, refers to the creation of correct examples of language use.

\subsection{Communicative Activities to Teach English}

Richards (2006) proposed two methodologies to achieve the goal of communicative language teaching; these process-based methodologies are Content-based instruction (CBI) and Task-based instruction (TBI). CBI is a methodology that favors the acquisition of language through the use of content; in addition, it allows to link and develop different language skills. While in TBI, pedagogical and real-world tasks are used in order to provide learners with opportunities to be involved in meaningful tasks. The former are tasks in which interaction among learners is necessary but the task itself will not be found in the real world while the latter are tasks designed from authentic materials such as listening tasks, problem solving, sharing personal experiences, comparing, among other real life situations.

As Richards and Rodgers (2014) report, there is more information about Communicative language teaching than learning theory. For this reason, they believe that it is necessary to discuss about the three elements of the learning theory that can be distinguished in some communicative language teaching practices. The first element is the communication principle that relates to the activities focused on the use of real communication. The second is the task principle which focuses on the use of language to carry out meaningful tasks. Finally, the third one is the meaningfulness principle in which the language used must be meaningful to the learner.

There is a great number of activities aimed at developing learners' communicative competence using communicative processes, such as information sharing, negotiation of meaning, and interaction. Similarly, the use 
of games, role plays, simulations, and task-based communication activities are necessary to support classes in which the Communicative language teaching approach is used (Richards and Rodgers, 2014). Similarly, Colker (2007) claims that students learn better by using their senses when they see, hear, touch, move, examine, smell, and even when they are provided with opportunities to taste things. She believes that students learn better when they have direct contact with the materials.

Additionally, Abe (2013) claims that group activities and individual development, discussions and presentations are useful in classrooms where the CLT approach is applied. Moreover, the author states that the constant use of English among students improves their speaking, although it may result stressful for them. For this reason, it is necessary to find effective ways to adapt English teaching using group work activities.

\subsection{Promoting Interaction in the English Classroom by Applying the Appropriate Teaching Materials}

Interaction plays an important role in language learning since it gives the students the opportunity to put into practice their communication skills. In order to create meaningful interaction among learners, the correct materials that promote such interaction have to be chosen. Richards (2001) states that materials are the key element in language learning whether they are textbooks, materials provided by an institution or materials made by the instructor. All these materials have the purpose of providing students with the basis for the language practice students receive in the classroom (as cited in Mcgrath, 2013).

Regarding the importance of using appropriate material, Schiffrin (1996) points out that traditional books very often provide insufficient content of the target language and they fail to give students enough communicative input (as cited in Peacock,1997). Moreover, the author observes that incorporating authentic materials such as the use of audio-visual material will offer richer contribution to learners which can be exploited in different ways and levels to improve their communication skills. In addition to the use of authentic materials in the classroom, Swaffar and Vlatten (1997) state that using video in the classroom exposes learners to authentic voices and different dialects, which provides them with cultural backgrounds (as cited in Salaberry, 2001). Moreover, Bahrani and Shu Sim (2011) assert that the use of TV and visual media cannot only be considered tools for entertainment but also pedagogical technology. In addition, the same author explains that by using news videos, the learners will be able to learn the structures used in a way that is clear and direct. News try to catch the viewers' attention; therefore, writers use vocabulary that is easily understood by the viewers. According to Yükselir and Kömür (2017), the use of online videos in the English classroom allows students to communicate and interact in a proper way to develop the competence to transmit messages in an easy way.

Furthermore, Peacock (1997) explains that a great number of authors believe that the use of authentic materials motivates learners in foreign language classes. They also believe that authentic materials are naturally interesting and motivating than materials that are not authentic.

\subsection{Assessment and Feedback}

According to Brown and Abeywickrama (2010), assessment is a continuous process that involves different methodological techniques. For Broadfoot, Weeden, and Winter (2002, p. 12), "it is a neutral instrument which is capable of measuring in individual's level of achievement objectively".

Assessing speaking seems to be an easy task because it can be directly observed but according to Weeden, Winter, and Broadfoot (2002) it can be a challenge because "those observations are invariably colored by the accuracy and effectiveness of a test-taker's listening skill, which necessarily compromises the reliability and validity of an oral production test" (p. 183). The results of the assessment and the feedback that teachers provide to those results are related to the students learning, that is why, it is important to give appropriate feedback when assessing. Lightbown and Spada (2006) state different ways to provide oral feedback. The first one is explicit correction which takes place when teachers provide the correct form by clearly indicating where the mistake was. The second one is recasts which refers to the teachers' reformulation of all or part of a learner's utterance without repeating the error. The next one is clarification request which occurs when teachers ask students to repeat or reformulate an utterance because it was misunderstood or incorrect.

Teachers do it by using clarification requests. Metalinguistic feedback involves questions, comments or information that teachers give students to help them to understand the mistake without providing the correct form of the utterance. Elicitation involves the use of three techniques to help students correct the mistake by themselves; teachers elicit completion of their own utterance, teachers use questions to elicit correct form, and teachers ask students to reformulate their utterance. The last way of providing oral feedback is repetition that involves the teacher's repetition of the student's wrong utterance. Sometimes intonation can be adjusted to make students be aware of the mistake. 
The use of any of the previously mentioned types of feedback will depend on teachers and students' preferences and also on the type of activities being carried out.

\subsection{Previous Studies}

Several studies have been carried out along the time with the purpose of improving the oral communication skills which is the major concern nowadays.

Nunan (1987) carried out a study which had the objective of researching about the degree to which characteristics of genuine communication was evident in communicative language classes, and whether strategies could be developed to encourage such communication. Considering this purpose, five communicative language classes were recorded, transcribed, and analyzed. Communicative language activities were used in these classes. Those activities included an elaborate jigsaw listening task, a map reading exercise, a discussion class based on recordings of casual conversations, simulated interviews in which students had to provide personal details, and a comprehension class based on radio advertisements and pictures of magazines. This classroom-based study revealed the lack of communicative patterns of interaction.

Chen (2015) conducted a study to research about the effects of practicing CLT in a mixed English conversation class. The purpose was to examine if L1 is necessary in CLT classrooms and if its use help learners to improve their learning attitudes through the following questions: What are the effects of implementing CLT in a mixed English conversion class? Should L1 be used in CLT classroom? Are students improving their learning attitudes and becoming active learners after the teaching methods were modified?

The results showed that learners were comfortable with the incorporations of CLT in the class; it was also evidenced that the use of the mother tongue could reduce learners' anxiety when they are not confident in the CLT classroom. In fact, after the modification of teaching methods that involved the use of L1, visual aids like pictures, short videos, and role playing in the CLT classroom, students showed more positive learning attitudes and became active learners.

Bruner, Sinwongsuwat and Radic-Bojanic (2015) carried out a study to detect how CLT contributed to foster communicative competence in two universities in Thailand. This study has the purpose of finding possible solutions to the classroom practices for improving the oral English proficiency of the majority of university low proficiency learners in Thailand. Teachers' experience, observations, and the findings from a questionnaire survey were the instruments used to detect the English proficiency level of students taking English communication courses at two universities in Thailand during a scholar year per university.

Classes at using CLT were based on the use of meaningful communicative contexts encouraging students to use English to express their ideas in authentic and rea world communication, feedback was very important to let students improve their communicative skills, and errors were tolerated just in case they did not interfere the meaning of the real message.

In both universities, material to promote communication through CLT was used, collaborative activities were emphasized, and both groups did their best, sometimes, it turned to be difficult to group up students because of the different English level they had, being one possible solution to give students a placement test so later they could be grouped homogeneously. Big groups represented also another problem because it was challenging for the teacher to monitor their students' performance in communicative activities. Students from one university were observed to have more group work accustomed activities in relation to the students from the other university, so cooperative activities should be encouraged more and finally, scripted and non-scripted dialogues took place in both groups of students, being the last ones the more productive because they gave students the opportunity to express freely their ideas at creating spontaneous dialogues that allow them to perform better orally.

The results of this study clearly demonstrate that authentic language contexts allow students to put into practice all the principles they have learned in classes; moreover, trying to use English independently will definitely be an illustration of authentic language application they will use when performing as professionals.

Muslem, Mustafa, Usman and Rahman (2017) carried out a study where they made use of video clips to find out if the students improved their speaking skills. For this study, a pre-test and a post-test were given to the students. The students were young learners, who were participants in small groups and individual work. After analyzing and comparing the results from the pre-test and post-test, the authors concluded that the video clips helped improve the speaking skills in group work more than it improved the speaking skills on students who were working on the activities individually. Based on these results, the authors suggest the implementation of video clips in small group activities using techniques such as slowing down videos and replaying important parts of the video. 


\section{Method}

\subsection{Participants}

The current study was conducted at a public school located in the south part of Loja, Ecuador. The sample consisted of six English teachers and their 105 students of second, third, and fourth grades of an elementary school.

\subsection{Procedures}

This study was conducted through the use of a mixed method approach. A questionnaire that included closed-ended and open-ended questions and an observation sheet were the instruments designed to collect data from the field research. Both instruments were written in English. The questionnaire was given to teachers before the observations; the aim of this instrument was to collect information about teachers' opinions regarding the use of the communicative language teaching approach to foster students' speaking skills, whereas the purpose of the observation sheet was used to take notes about the different activities and strategies being applied by teachers and their implications on the students. The observations were conducted during three classes per grade within a period of four weeks. The results obtained from the observations were used to confirm and compare the information obtained from the teachers. To provide qualified instruments, a validation process, which consisted in delivering the questionnaire and the observation sheet to English teacher colleagues, was carried out.

\section{Findings and Discussion}

This section presents and analyzes the findings obtained in this study related to the activities, strategies, materials, types of feedback and the percentage of language used in the classrooms which are considered when using the communicative language teaching approach.

Table 1. Communicative language teaching aspects

\begin{tabular}{|c|c|c|c|c|c|}
\hline \multirow[t]{2}{*}{$\mathrm{N}$} & & YES & $\%$ & NO & $\%$ \\
\hline & \multicolumn{5}{|l|}{ Task-Based Activities } \\
\hline 1 & Find a friend who & 0 & $0 \%$ & 6 & $100 \%$ \\
\hline 2 & Making plans & 1 & $17 \%$ & 5 & $83 \%$ \\
\hline 3 & Games & 5 & $83 \%$ & 1 & $17 \%$ \\
\hline 4 & Drawing activities & 3 & $50 \%$ & 3 & $50 \%$ \\
\hline 5 & Role-Plays & 6 & $100 \%$ & 0 & $0 \%$ \\
\hline \multirow[t]{2}{*}{6} & Dramatizations & 3 & $50 \%$ & 3 & $50 \%$ \\
\hline & \multicolumn{5}{|l|}{ Hands-on Activities } \\
\hline 7 & Vocabulary practice (word cards) & 6 & $100 \%$ & 0 & $0 \%$ \\
\hline 8 & Sentence strips & 4 & $67 \%$ & 2 & $33 \%$ \\
\hline 9 & Graphic organizers & 4 & $67 \%$ & 2 & $33 \%$ \\
\hline 10 & Manipulatives & 2 & $33 \%$ & 4 & $67 \%$ \\
\hline \multirow[t]{2}{*}{11} & Projects & 4 & $67 \%$ & 2 & $33 \%$ \\
\hline & \multicolumn{5}{|l|}{ Authentic Materials } \\
\hline 12 & Videos & 2 & 33 & 4 & 67 \\
\hline 13 & Photos & 6 & $100 \%$ & 0 & $0 \%$ \\
\hline 14 & Conversations & 6 & $100 \%$ & 0 & $0 \%$ \\
\hline 15 & Audiovisuals & 3 & $50 \%$ & 3 & $50 \%$ \\
\hline 16 & Visuals & 3 & $50 \%$ & 3 & $50 \%$ \\
\hline \multirow[t]{2}{*}{17} & Realia & 4 & $67 \%$ & 2 & $33 \%$ \\
\hline & \multicolumn{5}{|l|}{ Strategies to provide meaningful input } \\
\hline 18 & Body language & 6 & $100 \%$ & 0 & $0 \%$ \\
\hline 19 & Modeling & 6 & $100 \%$ & 0 & $0 \%$ \\
\hline
\end{tabular}




\begin{tabular}{llllll}
\hline 20 & Gestures & 6 & $100 \%$ & 0 & $0 \%$ \\
21 & Visuals & 4 & $67 \%$ & 2 & $33 \%$ \\
22 & Repetitions & 6 & $100 \%$ & 0 & $0 \%$ \\
23 & Slower speech rate & 2 & $33 \%$ & 4 & $67 \%$ \\
& Types of feedback provided & & & & \\
24 & Explicit correction & 3 & $50 \%$ & 3 & $50 \%$ \\
25 & Recast & 2 & $33 \%$ & 4 & $67 \%$ \\
26 & Clarification request & 2 & $33 \%$ & 4 & $67 \%$ \\
27 & Metalinguistic feedback & 4 & 67 & 2 & 33 \\
28 & Elicitation & 3 & $50 \%$ & 3 & $50 \%$ \\
29 & Repetition & 2 & $33 \%$ & 4 & $67 \%$ \\
& Percentage of English used in the classroom & & & & \\
30 & $90 \%$ a 100\% & 0 & $0 \%$ & 6 & $100 \%$ \\
31 & $60 \%$ a $80 \%$ & 4 & $67 \%$ & 2 & $33 \%$ \\
32 & $30 \%$ a 50\% & 2 & $33 \%$ & 4 & $67 \%$ \\
\hline
\end{tabular}

As it can be observed in the Table, according to the surveyed teachers, the finding a friend who activity is not used in the classroom since $100 \%$ of the teachers answered $N O$ to this question. Regarding the making plans activity, $83 \%$ of the teachers do not use it while only $17 \%$ mentioned they do use it. Games are one of the activities that are used by the majority of teachers which corresponds to $83 \%$; only $17 \%$ do not use them in the classroom. Another task-based activity is drawing which is used by $50 \%$ of the teachers. The same percentage of teachers use dramatizations while the other $50 \%$ avoid using them. The last task-based activity included in the list is role plays which is used by all the surveyed teachers. As this table shows task-based activities are being used by teachers and it represents an advantage for learners since as Richards (2016) mentions task-based activities provide learners opportunities to be involved in meaningful tasks.

During the observation, it was noticed that the use of dramatizations took place since 50 percent of the teachers created spaces where students had the opportunity to produce the target language and interact face to face in a non-real context and in this way they reached the goal of communicating. While working with dramatizations, it was noticed that learners felt more confident and motivated to participate because it was an interesting strategy for them. On the other hand, the use of the rest of activities was not evident, then what was mentioned by the interviewed teachers was not corroborated. It is important to highlight that the use of task-based activities motivate students to learn the English language and provides good results because they help students become active learners during the classes. It was evident in the result obtained in the study carried out by Chen (2015) which demonstrated that the use of these type of activities helped students to have more positive learning attitudes and to become active learners.

It is also observed that $100 \%$ of the surveyed teachers use word cards to practice vocabulary. Regarding the use of sentence strips and graphic organizers, $67 \%$ of the teachers mention that they use them to make students practice the language while $33 \%$ do not use them. While observing the classes performed by these teachers, the use of these hands-on activities was not confirmed at all because only $30 \%$ of the teachers approximately use them having as a result motivated students who were willing to participate during the whole class. The use of this strategy favor communication in the classroom in the sense that learners interacted with their teachers and classmates; for example, they interacted with the teacher when asking for reinforcement during the completion of the activities and they did it with their classmates in order to complete the assigned tasks. It is important to highlight that if teachers do not make use of hands-on activities, they are not allowing students to have the opportunity to actively participate in a good learning environment that provides positive outcomes. According to Richards (2006), learning the language does not always guarantee the learner will be able to use the language fluently. For this reason, it is of paramount importance that teachers use some strategies that favor the use of the language in the English classroom to improve fluency.

Regarding the use of manipulatives, 33\% of teachers confirmed they use them, while $67 \%$ mentioned that they do not use them as to promote students' speaking skills. According to Corrales (2010) manipulatives are not only used 
for teaching mathematics but for language instruction as well, since the use of them benefit both kinesthetic and visual learners, they capture the students' interest, help them become active learners, and reinforce content material in an effective way. Concerning projects $66,6 \%$ of teachers said they use this hands-on activity whereas $34,4 \%$ of them do not use them in their classes. The observations corroborated that teachers did not use manipulatives to promote students' oral production. It was also evidenced that even most of the teachers indicate that they use projects in their lessons, none of them used this strategy during the observations.

In regard to authentic materials, the results in the Table show that $33 \%$ of the teachers use videos, whereas $67 \%$ of them, do not use videos to foster students' participation in communicative activities. Other materials teachers counted on were photos and conversations, which were used by them in a $100 \%$. With respect to the use of audiovisual and visuals, half of the sample 50\% used them. In the case of the use of realia $67 \%$ of the teachers mentioned they use this as a valuable resource to foster students' desire to express their thoughts, on the other hand, $33 \%$ of the teachers do not use realia in their classes, limiting the possibility for students to use this important and accessible material to promote students' willingness to talk. Recent studies as the one done by Setyawan (2017) have shown that the use of realia does help students to improve the speaking skill significantly, students achieve high in tests when using real objects as material to incorporate vocabulary for the students to use in daily conversations. In spite of all the advantages that the use of videos, audiovisual and visual material offers, it was observed that most of the teachers do not use these valuable resources in their classes.

Regarding the ways of grouping students, $100 \%$ of the teachers use both pair and group work. It was evident that having students work in groups increases their motivation to use the language and promotes opportunities to learn from each other; however, during the observations, it was noticed that just $50 \%$ of them use pair and group work in the English classroom.

According to a study done by Sakarkaya (2013) when students are arranged in pair or group work, they have the opportunity to improve their speaking skills, students usually feel more confident, comfortable and free expressing their ideas without being afraid of making mistakes while in both pair or group work activities; correction usually takes place among students in the group.

As shown in the Table, a considerable number of teachers indicated that a variety of strategies to provide meaningful input is used in their lessons. A hundred percent of them assured that body language, modeling, and gestures are applied in their lessons because these strategies help learners to easily understand content and know exactly what they are asked to do. Some well-known authors have contributed with important information that show the importance of using strategies that help to provide meaningful input; for example, Engelkamp and Krumnacker 1980; Saltz and Donnenwerthnolan 1981 argued that actions words or phrases can be memorized better when learners act out the action (as cited in Macedonia and von Kriegstein, 2012). Similarly, 67\% of teachers indicated that they use visuals during their lessons since these materials provide additional support to learners and increase their understanding; on the contrary, $33 \%$ of teachers indicated that they do not use visuals in their lessons. According to Herrel and Jordan (2015), visuals allow learners to connect English words with the images being displayed which constitute a good reason for English teachers to incorporate visuals in their lessons. It was also found in the results that $100 \%$ of teachers use repetitions in their lessons especially when the language is hard for learners to understand. A smaller percentage of teachers (33\%) reported that they slow their speech rate to allow learners to understand the message which is a good strategy to reduce students' anxiety as well. On the contrary, $67 \%$ of teachers indicated that they do not consider important to slow speech rate because content is not difficult.

The results obtained from the observations reveal that a considerable number of teachers use modeling and repetitions as strategies to provide learners with opportunities to learn the language in a meaningful way. In fact, learners felt confident during these classes because with the use of modeling, they were able to know exactly what teachers expected from them. It is also remarkable that even though more than $66 \%$ of teachers indicate that they use visuals and body language, the results from the observations show that they do not use visuals and just a few of them use body language in their lessons.

As it is presented in Table, fifty percent of teachers provide learners with explicit corrections in order to allow them identify any possible mistake. Lightbown and Spada (2006) claim that this type of feedback is applied when the teacher clearly shows the learner what the mistake was. On the other hand, $50 \%$ of teachers claim that they do not use this kind of correction to provide feedback. Regarding the use of recasts, only $33 \%$ of teachers use this type of feedback while $67 \%$ do not use recast as a way of giving feedback. Even though two teachers stated that they used recast, the observation carried out in class tells us that only one of the teachers used this type of feedback. This may occur due to teachers applying other ways to give feedback such as the metalinguistic feedback, which was used 
the most according to the data collected. Regarding the use of clarification request as a way to give feedback, half of the teachers $33 \%$ use it, and $67 \%$ do not use this type of feedback. Through the observation, most of the teachers did not use questions such as "Excuse me?" "say again?" or "I don't understand" to try to correct the students' utterances. When using Metalinguistic Feedback $67 \%$ of the teachers stated that they use this type of feedback compared to a $33 \%$ of teachers who do not use it. This may happen because teachers are used to give detailed explanation using grammar structures and examples. Also, most of the teachers find an opportunity to review what has been learned and do not correct every mistake students make in order for them to spot the mistake. Regarding the use of elicitation, the results show that $50 \%$ of teachers use this way of giving feedback and the other $50 \%$ of teachers do not use elicitation meaning that some teachers allow some time to have students come up with the correct information by prompting them to repeat the utterance. The results also show us that $66 \%$ of the teachers do not use repetition and $33 \%$ of the teachers use repetition when giving feedback. Some teachers may prefer to correct the mistake when it is made, and they usually repeat the students' utterances in form of a question and changing the intonation to allow the students to quickly analyze and the mistake made and the necessary correction. Through the observations, it was evidenced that most of the teachers used metalinguistic and elicitation feedback to correct students' mistakes because in this way, they did not interrupt students when producing the language; instead, teachers looked for the best opportunities to provide the most favorable input through continuous oral interaction.

Regarding the use of English in the classroom by the teachers, the results show us that a hundred percent of them do not use the target language in a $90 \%-100 \%$ of the time. The teachers also express that sixty-six percent of them use the language in a $60 \%-80 \%$ of the time, while thirty-three percent do not use the language in that percentage. Finally, only thirty-three percent of the teachers use the language from $30 \%$ to $50 \%$ of the time.

\section{Conclusions}

The results of this study provide evidence that the only task-based activity used during the classes was dramatizations while hands-on activities were not commonly used. Regarding strategies to develop English learners' communicative competence; modeling, repetition, pair and group work were the most used ones. Even though these strategies are used, their application in the English classroom is not providing the desired results because they were not used as frequent as they were necessary to provide learners with more opportunities to use the language to orally interact; therefore, it is necessary to use them more often and incorporate more strategies to help students develop communicative competence and enhance their active participation in oral activities. The findings also show that students are provided with metalinguistic and elicitation feedback to improve their communicative skills which allow learners to be aware of their mistakes while receiving input from the teacher through oral interaction.

Further research about the application of activities, strategies, and materials used in communicative language teaching approach should be done to analyze the benefits students can obtain when using them.

\section{Acknowledgments}

Our special gratitude goes to all the people who contributed to the development of this study. Especially to all teachers and students who provided valuable information to get important conclusions to improve English teaching quality. Additionally, we want to thank to all the principals, who allowed us to conduct our study in the institutions they manage.

\section{References}

Abe, E. (2013). Communicative language teaching in Japan: Current practices and future prospects: Investigating students' experiences of current communicative approaches to English language teaching in schools in Japan. English Today, 29(2), 46-53. https://doi.org/10.1017/S0266078413000163

Brown, D., \& Abeywickrama, P. (2010). Language Assessment: Principles and Classroom Practices. New York: Pearson Education. https://doi.org/10.1080/10627197.2010.530562

British Council. (2015). English in Ecuador: An examination of policy, perceptions and influencing factors. Retrieved from https://ei.britishcouncil.org/sites/default/files/latin-america-research/English\%20in \%20Ecu ador.pdf

Broadfoot, P., Weeden, P., \& Winter, J. (2002). Assessment: What's in it for Schools?. Routledge.

Bruner, D. A., Sinwongsuwat, K., \& Radic-Bojanic, B. (2015). EFL Oral Communication Teaching Practices: A Close Look at University Teachers and A2 Students' Perspectives in Thailand and a Critical Eye from Serbia. English Language Teaching, 8(1), 11-20. 
Calle, A., Calle, S., Argudo, J., Moscoso, E., Smith, A., \& Cabrera, P. (2012). Los profesores de inglés y su práctica docente: Un estudio de caso de los colegios fiscales de la ciudad de Cuenca, Ecuador. Maskana, $3(2), 1-17$.

CaoBahrani, T., \& Shu Sim, T (2011). The role of audionvisual mass media news in language learning. English Language Teaching, 4(2), 260-266. https://doi.org/10.5539/elt.v4n2p260

Chen, W. (2015). A case study of action research on communicative language teaching. Journal of Interdisciplinary Mathematics, 18(6), 705-717. https://doi.org/10.1080/09720502.2015.1108075

Colker, L.J. (2007). Hand-on Learning. Washington, DC: National Association for the Education of Young Children.

Corrales, K. (2010). Getting your hands on learning: Manipulative tools in content ESL/EFL instruction. Latin American Journal of Content \& Language Integrated Learning, 1(1), 60-65. https://doi.org/10.5294/laclil. 2008.1.1.7

Jeyasala, V. R. (2014). A prelude to practice: Interactive activities for effective communication in English. Alternative pedagogies in the English language \& communication classroom, 164-170.

Lightbown, P., \& Spada, N. (2006). How Languages are Learned. Oxford University Press.

Macedonia, M., \& von Kriegstein, K. (2012). Gestures enhance foreign language learning. Biolinguistics, 6(3-4), 393-416.

McGrath, I. (2013). Teaching materials and the roles of EFL / ESL teacher: Practice and theory. New York: Bloomsbury Academic.

Moss, D., \& Ross-Feldman, L. (2003). Second language acquisition in adults: From research to practice. Retrieved from http://www.cal.org/CAELA/esl_resources/digests/SLA.html

Muslem, A., Mustafa, F., \& Rahman, A. (2017). The application of video clips with small group and individual activities to improve young learners' speaking performance. Teaching English with Technology, 17, 25-37.

Nunan, D. (1987). Communicative Language Teaching: Making it work. ELT Journal, 38(2), 136-145. https://doi.org/10.1093/elt/41.2.136

Peacock, M. (1997) The effect of authentic materials on the motivation of EFL learners. ELT Journal, 51(2), 144-156. https://doi.org/10.1093/elt/51.2.144

Richards, J. C. (2006). Communicative language teaching today. SEAMEO Regional Language Centre.

Richards, J. C., \& Rodgers, T. S. (2014). Approaches and methods in language teaching. Cambridge: Cambridge University Press.

Sakarkaya, V. (2013). 12 Pair and group work activities: Keep them or leave them?. Teacher-researchers in acTion, 163.

Salaberry, R. (2001). The use of Technology for Second Language Learning and Teaching: A Retrospective. Modern Language Journal, 85(1), 39-56. https://doi.org/10.1111/0026-7902.00096

Setyawan, E. (2017). Using Realia In Speaking Class. Karya Ilmiah Mahasiswa Progdi Pendidikan Bahasa Inggris FKIP, 3(1).

Yükselir, C., \& Kömür, S. (2017). Using Online Videos to Improve Speaking Abilities of EFL Learners. Online Submission, 3(5), 255-266.

\section{Copyrights}

Copyright for this article is retained by the author(s), with first publication rights granted to the journal.

This is an open-access article distributed under the terms and conditions of the Creative Commons Attribution license (http://creativecommons.org/licenses/by/4.0/). 